\title{
硝化促進型循環変法の脱窒速度に及ぼす 有機物負荷と水温の影響
}

\author{
中村裕紀 ${ }^{1} \cdot$ 江森弘祥 $^{2} \cdot$ 竹島 正 $^{3} \cdot$ 田中和博 ${ }^{4}$ \\ 1正会員 日立プラント建設株式会社 松戸研究所（テ271 千葉県松戸市上本郷船付 537） \\ ${ }^{2}$ 正会員 工修 日立プラント建設株式会社 水処理事業部 (テ170 東京都豊島区北大塚 1-13-2) \\ 農修 日本下水道事業団 技術開発部（ $\bar{T} 335$ 埼玉県戸田市下笹目 5141） \\ ${ }^{4}$ 正会員 工博 日本大学教授 土木工学科（テ101 東京都干代田区神田駿河台 1-8）
}

\begin{abstract}
硝化促進型循環変法における浮遊污泥の脱空性能に及ぼす有機物負荷（BOD-SS負荷）と水温の影響を検討 した. 単位污泥量あたりの脱窒速度 $K_{D N}$ は, 污泥内に蓄積される有機物量 $A$ とその代謝速度定数 $k$ の積に比例 する式 $K_{D N}=(\mathrm{k} / \mathrm{m}) \cdot A(\mathrm{~m}$ は定数 $)$ で表現できる. 水温が $12 \sim 27^{\circ} \mathrm{C}$ の範囲においては水温が低いほど $k$ が小 さくなり, その結果として $A$ が増加するため $K_{D N}$ はあまり変化しない。一方, $A$ は有機物負荷にほぼ比例する ため， $K_{D N}$ は有機物負荷にほぼ比例するとみなせることが明らかになった.
\end{abstract}

Key Words : wastewater treatment, nitrogen removal, immobilized nitrifiers, denitrification rate

\section{1.はじめに}

廃水の窒素除去方法として, 従来の活性污泥循環変法 の硝化槽に硝化菌の包括型固定化担体を添加したプロセ スが開発され, 実用化に至っている.この硝化促進型循 環変法は, $6 \sim 8$ 時間の反応槽滞留時間で下水の $\mathrm{BOD}$ 成分を $90 \%$ 程度, 窒素成分を $70 \%$ 程度まで同時に除去 できるものである. また, 従来の循環変法と比較して硝 化槽容積が $1 / 3 \sim 1 / 4$ に縮小され，これにより脱窒槽を 含めた反応槽全体の容積が約 $1 / 2$ とコンパクトになる特 長をもつ ${ }^{1}$. このような硝化性能の大幅な改良に付随し て, 浮遊污泥の脱窒性能についても, 単位污泥量あたり の脱窒速度が大きくなるという報告がされ始めてい $ろ^{2), 3)}$. この原因は, 反応槽容積が小さくなることによ り単位污泥量あたりの有機物負荷 (BOD-SS 負荷) が 高くなり，脱窒に利用できる有機物量が増加するため之 推定される. しかしながら, 脱窒速度の増加因子につい ての解明は不十分であり, 脱窒槽の最適運転のための指 針も明確になっていない.

一般に活性污泥中の脱窒菌による脱窒反応は, 硝酸性 窒素 $\left(\mathrm{NO}_{3}-\mathrm{N}\right)$ の還元のための水素供与体として廃水 中の有機物を利用し, その速度は有機物の除去速度と直 線関係にあることが合成廃水を用いた検討で明らかにさ れている4). また, 液相中に有機物が存在しなくても, 污泥内に蓄積・吸着された有機物を利用する脱窒反応が 可能であり, 下水の BOD-SS 負荷が $0.1 \mathrm{~kg} \mathrm{BOD}_{5} /$
$\mathrm{kg}-\mathrm{SS} / \mathrm{d}$ 程度までの範囲で污泥内有機物量の間接的な 定量化が試みられるとともに, 脱窒速度との関係が論じ らている5).

今回, 硝化促進型循環変法で下水を処理した場合につ いて，重要な因子と考えられる BOD-SS 負荷と水温が 脱窒速度に及ぼす影響を検討することとした。特に BOD-SS 負荷が従来より高い $0.1 \mathrm{~kg}-\mathrm{BOD}_{5} / \mathrm{kg}-\mathrm{SS} / \mathrm{d}$ $\left(4.2 \mathrm{mg}-\mathrm{BOD}_{5} / \mathrm{g}-\mathrm{SS} / \mathrm{h}\right)$ 以上までの領域について污 泥内有機物量の算定を試み, 脱窒速度との関係を明らか にすることとした。

\section{2. 実験方法}

\section{（1）実験装置及び実験材料}

\section{a) 連続処理装置及び方法}

下水の連続処理装置として, $\mathrm{K}$ 市 $\mathrm{T}$ 処理場で硝化促 進型循環変法で運転中の実証装置, 及び $\mathrm{H}$ 市 $\mathrm{K}$ 処理場 で硝化促進型循環変法之従来の活性污泥偱環変法の性能 比較を行っている 2 系列のパイロットプラント（以下， それぞれ PP 1, PP 2 と言う.) の合計 3 系列を使用し た. いずれも, 最初沈殿池の流出水を原水としている. 装置のフロー概要を Fig.1 に, 各系列の反応槽の仕様概 要と, 約 1 年間の運転条件をまとめて Table 1 に示す. 実証装置と PP 1 の硝化槽には, 包括固定化担体を硝化 槽容積あたり $7.5 \%$ 添加した，反応槽の滞留時間（平均 値）は，実証装置とPP 1 で 7 8 時間, PP 2 で約 13 
Table 1 Reactors specifications and operational conditions (Avarage and [Min. Max.])

\begin{tabular}{|c|c|c|c|}
\hline & Demonstration plant & P P 1 & P P 2 \\
\hline $\begin{array}{ll}\begin{array}{c}\text { Reactor volume } \\
\text { Total }\end{array} & \left(\mathrm{m}^{3}\right) \\
\begin{array}{c}\text { Denitrification tank } \\
\text { Nitrification tank }\end{array} & \left(\mathrm{m}^{3}\right) \\
\text { N })\end{array}$ & $\begin{array}{lll}7 & 5 & 0 \\
4 & 5 & 0 \\
3 & 0 & 0\end{array}$ & $\begin{array}{l}7.2 \\
4.3 \\
2.9\end{array}$ & $\begin{array}{l}8.6 \\
4.7 \\
3.9\end{array}$ \\
\hline $\begin{array}{l}\text { Nitrification tank } \\
\quad \text { volume ratio* (-) }\end{array}$ & 0.40 & 0.40 & 0.45 \\
\hline Pellet dosing ratio $\quad(\%)$ & $\begin{array}{r}7 . \\
\text { (Pellet volume } / \text { Nitri }\end{array}$ & cation tank volume) & 0 \\
\hline Inflow rate & $\begin{array}{c}2,340 \\
{[2,250 \sim 2,400]} \\
\end{array}$ & $\begin{array}{c}23.0 \\
{[21.3 \sim 38.4]}\end{array}$ & $\begin{array}{c}15.6 \\
{[10.1 \sim 18.6]}\end{array}$ \\
\hline Retention time & $\begin{array}{c}7.7 \\
{[7.5 \sim 8.0]} \\
\end{array}$ & $\begin{array}{c}7.5 \\
{[4.5 \sim 8.1]} \\
\end{array}$ & 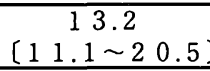 \\
\hline $\begin{array}{l}\text { Nitrified liquor } \\
\text { recycling ratio }\end{array}$ & $\begin{array}{c}2.4 \\
{[2.0 \sim 3.5]} \\
\end{array}$ & $\begin{array}{c}2.9 \\
{[2.7 \sim 3.1]} \\
\end{array}$ & $\begin{array}{c}3.5 \\
{[2.8 \sim 4.2]} \\
\end{array}$ \\
\hline MLS S & $\begin{array}{c}1.68 \\
{[0.76 \sim 2.45]}\end{array}$ & $\begin{array}{c}1.28 \\
{[0.63 \sim 2.69]}\end{array}$ & $\begin{array}{c}1.81 \\
{[0.60 \sim 3.98]}\end{array}$ \\
\hline $\begin{array}{l}\text { B O D-S S loading } \\
\text { (mg-BODs/g-SS/h) }\end{array}$ & $\begin{array}{c}5.71 \\
{[2.96 \sim 7.92]}\end{array}$ & $\begin{array}{c}7.29 \\
{[3.25 \sim 14.5]} \\
\end{array}$ & $\begin{array}{c}3.04 \\
{[0.83 \sim 7.46]}\end{array}$ \\
\hline Temperature & 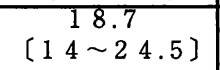 & $\begin{array}{c}20.8 \\
{[12 \sim 27]}\end{array}$ & $\begin{array}{c}21.1 \\
{[12 \sim 27]}\end{array}$ \\
\hline
\end{tabular}

* Nitrification tank volume / Total reactor volume

Table 2 Performance of wastewater treatment

\begin{tabular}{|c|c|c|c|c|}
\hline & \multicolumn{3}{|c|}{ Average concentration [Min. $\sim$ Max.] } \\
\hline & & \multicolumn{2}{|r|}{ Influent } & Effluent \\
\hline \multirow{5}{*}{ D P } & $\mathrm{BOD}$ & 75.2 & {$[28.8 \sim 134.0]$} & {$[1.0 \sim$} \\
\hline & $\mathrm{S}-\mathrm{BOD}$ & 38.4 & {$[8.9 \sim 75.4]$} & $1.0 \sim 3.9]$ \\
\hline & $\mathrm{T}-\mathrm{N}$ & 25.8 & $8.0 \sim 48.0]$ & $3.4 \sim 8.1]$ \\
\hline & $\mathrm{NH} 4-\mathrm{N}$ & 17.8 & {$[3.7 \sim 34.0]$} & $0.02 \sim 0.423$ \\
\hline & $\mathrm{NO}_{3}-\mathrm{N}$ & 0.61 & {$[0.03 \sim 1.3]$} & $3.1 \sim 7.1]$ \\
\hline \multirow{5}{*}{$\begin{array}{c}\mathrm{P} P \\
1\end{array}$} & BOD & 60.9 & {$[34.4 \sim 86.7]$} & $6.0 \sim 16.1]$ \\
\hline & S-BOD & 39.2 & {$[27.2 \sim 61.0]$} & $1.0 \sim 6.4]$ \\
\hline & $\mathrm{T}-\mathrm{N}$ & 23.6 & {$[18.0 \sim 30.0]$} & $4.4 \sim$ \\
\hline & NH4-N & 17.8 & $13.0 \sim$ & $0.04 \sim 0.73$ \\
\hline & $\overline{\mathrm{NO}} 3-\mathrm{N}$ & 0.60 & $0.06 \sim$ & $3.0 \sim 5.9]$ \\
\hline \multirow{5}{*}{$\begin{array}{l}\mathrm{P} P \\
2\end{array}$} & $\mathrm{BOD}$ & 56.7 & {$[34.4 \sim 86.7]$} & $1.0 \sim 33.4$ \\
\hline & $S-B O D$ & 38.0 & {$[27.2 \sim 61.0]$} & $1.0 \sim 2.5]$ \\
\hline & T-N & 22.7 & $(18.0 \sim 28.0]$ & $6.1 \sim 18.0$ \\
\hline & NH4-N & 17.4 & $13.0 \sim 21.0$ & $0.84[0.06 \sim 7.1]$ \\
\hline & $\mathrm{NO}_{3-\mathrm{N}}$ & 0.53 & $0.06 \sim$ & {$[2.5 \sim 16.0]$} \\
\hline
\end{tabular}

D P: Demonstration plant s-B O D: soluble B O D

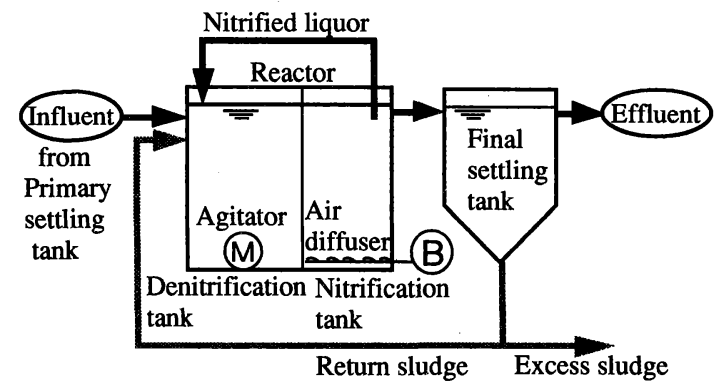

Fig.1 Schematic diagram of continuous treatment plant

時間である．滞留時間と污泥濃度の設定値及び原水の $\mathrm{BOD}$ 濃度が変化することにより, 年間を通して BOD-SS 負荷が 3 系列合わせて $0.83 \sim 14.5 \mathrm{mg}-\mathrm{BOD}_{5} /$ $\mathrm{g}-\mathrm{SS} / \mathrm{h}$ の間で変動した.
各系列における下水の連続処理状況を Table 2 に示 す. 溶解性 BOD（s-BOD）濃度は，いずれの系列でも $2 \mathrm{mg}-\mathrm{BOD}_{5} / \mathrm{L}$ 程度まで処理されていることから， BOD 成分の除去性能については系列による差はないも のと考えられる. また, アンモニア性窒素 $\left(\mathrm{NH}_{4}-\mathrm{N}\right)$ 濃度についても全系列で $1 \mathrm{mg}-\mathrm{N} / \mathrm{L}$ 以下まで処理され, ほぼ完全硝化されている.これに対し, 全窒素 $(T-N)$, 硝酸性窒素 $\left(\mathrm{NO}_{3}-\mathrm{N}\right)$ 濃度についてはPP 2 で他の系列 よりも処理水中に多く残存しており, 脱窒がやや不十分 であることが示される.

\section{b) 脱窒速度の算出及び測定用試料}

脱窒速度の算出及び測定には，連続処理装置から午前 10 時ごろに採取したスポット試料を用いた。連続処理 系における脱窒速度の算出のため, 脱窒槽污泥, 硝化槽 
污泥，及び返送污泥を採取し，それぞれの No. 5 A ろ紙 によるろ液と，同時刻に採取した原水を $\mathrm{NO}_{3}-\mathrm{N}$ 濃度の 分析に供した。また，脱窒槽污泥と硝化槽污泥（または 返送污泥を処理水で希釈した液）を脱窒速度の回分測定 及び污泥内有機物量の算定に供した。なお，原水の $\mathrm{BOD}$ と各槽の污泥濃度 (MLSS) の平均値から全槽の BOD-SS 負荷を求めた.

$\mathrm{K}$ 市 $\mathrm{T}$ 処理場及び $\mathrm{H}$ 市 $\mathrm{K}$ 処理場ともに，24 時間調 査における各時刻の原水の BOD 濃度と $\mathrm{T}-\mathrm{N}$ 濃度は, それぞれ夜間 $(21 ： 00 \sim 6: 00)$ には昼間の值の $40 \sim 90 \%$ 程度に低下するものの, 著しい濃度変動は見受けられず, 昼間には比較的安定して推移している ${ }^{1), 6)}$. 従って，原 水や各槽の污泥は同時刻のスポット試料ではあるが, BOD-SS 負荷や脱窒速度などについてそれらの関係を 直接論じられるものと判断し解析を行った。

\section{（2）脱窒速度の算出及び測定方法}

\section{a) 連続処理系における算出方法}

連続処理装置の各槽内の酸化態窒素のうち $\mathrm{NO}_{2}-\mathrm{N}$ 濃

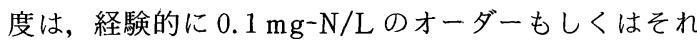
以下であることが確認されている．そこで， $\mathrm{NO}_{2}-\mathrm{N}$ 濃 度を無視し, 連続処理装置の脱窒槽における $\mathrm{NO}_{3}-\mathrm{N}$ 濃 度の変化量から, 単位污泥量あたりの脱窒速度 $\left(K_{D N}\right)$ を式（1）－式（3）により算出する.

$$
\begin{gathered}
K_{D N}=\left(N_{d i}-N_{d e}\right) / t d^{\prime} / X \\
N_{d i}=\left(N_{i}+N_{n e} \cdot R+N_{r} \cdot R^{\prime}\right) /\left(1+R+R^{\prime}\right) \\
t d^{\prime}=t d /\left(1+R+R^{\prime}\right)
\end{gathered}
$$

ここに, $K_{D N}$ : 脱窒速度 $(\mathrm{mg}-\mathrm{N} / \mathrm{g}-\mathrm{SS} / \mathrm{h})$

$N_{d i}$ : 脱窒槽流入 $\mathrm{NO}_{3}-\mathrm{N}$ 濃度 $(\mathrm{mg}-\mathrm{N} / \mathrm{L})$

$N_{d e}$ : 脱室槽流出 $\mathrm{NO}_{3}-\mathrm{N}$ 濃度 $(\mathrm{mg}-\mathrm{N} / \mathrm{L})$

$N_{i}$ : 原水 $\mathrm{NO}_{3}-\mathrm{N}$ 濃度 $(\mathrm{mg}-\mathrm{N} / \mathrm{L})$

$N_{n e}$ : 硝化槽流出 $\mathrm{NO}_{3}-\mathrm{N}$ 濃度 $(\mathrm{mg}-\mathrm{N} / \mathrm{L})$

$N_{r}$ : 返送污泥中 $\mathrm{NO}_{3}-\mathrm{N}$ 濃度 $(\mathrm{mg}-\mathrm{N} / \mathrm{L})$

$t d^{\prime}$ : 脱窒槽実滞留時間 $(\mathrm{h})$

$t d$ : 原水あたりの脱窒槽滞留時間 $(\mathrm{h})$

$X:$ 污泥濃度 $(\mathrm{g}-\mathrm{SS} / \mathrm{L})$

$R:$ 循環比 $(-)$

$R^{\prime}$ : 返送比 $(-)$

なお, $K_{D N}$ の $\mathrm{NO}_{3}-\mathrm{N}$ 濃度に関する半飽和恒数として $0.08 \sim 0.16 \mathrm{mg}-\mathrm{N} / \mathrm{L}$ が報告されており ${ }^{7)}, \mathrm{NO}_{3}-\mathrm{N}$ 濃度 による律速をほぼ無視できると考えられる $N_{d e}>0.2$ $\mathrm{mg}-\mathrm{N} / \mathrm{L}$ の場合につき $K_{D N}$ を算出する.

\section{b）脱窒速度の回分測定方法}

脱窒槽污泥に連続処理系外で十分な $\mathrm{NO}_{3}-\mathrm{N}$ を添加 し, 脱窒速度 $K_{D N}$ を回分測定した.

まず，脱窒槽污泥を容積が 1 または 2 L のガラス容 器にいれ, $6 \mathrm{~g}-\mathrm{N} / \mathrm{L}$ の濃度の $\mathrm{KNO}_{3}$ 溶液を初期濃度が
20〜100 mg-N/L 程度になるように添加した後，スター ラで覧挥し回分反応を開始する。ここで, $\mathrm{NO}_{3}-\mathrm{N}$ の初 期濃度は, 次項 ( 3 ) で述べる污泥内有機物量を同時に 算定するのに必要な 30 時間程度以上の脱窒回分反応を 行っても, $\mathrm{NO}_{3}-\mathrm{N}$ が残存するような低すぎない濃度に 設定する必要がある. ちなみに, $\mathrm{NO}_{3}-\mathrm{N}$ の初期濃度を $77.6 \mathrm{mg}-\mathrm{N} / \mathrm{L}$ 及び $173.2 \mathrm{mg}-\mathrm{N} / \mathrm{L} の 2$ 通りに設定し, 同一の脱窒槽污泥（污泥濃度 $2.66 \mathrm{~g}-\mathrm{SS} / \mathrm{L}$ ) を用いて

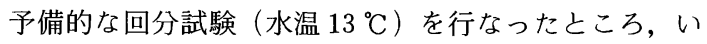
ずれの場合も各経過時間までの $\mathrm{NO}_{3}-\mathrm{N}$ 濃度の減少量は 同程度で, 例えば 72 時間までの減少量はそれぞれ $77.2 \mathrm{mg}-\mathrm{N} / \mathrm{L}, 74.1 \mathrm{mg}-\mathrm{N} / \mathrm{L}$ であった. さらに先に述 べた $\mathrm{NO}_{3}-\mathrm{N}$ 濃度に関する半飽和恒数が $0.1 \mathrm{mg}-\mathrm{N} / \mathrm{L} の$ オーダーである報告をも考慮し， $\mathrm{NO}_{3}-\mathrm{N}$ の初期濃度を 20 - $100 \mathrm{mg}-\mathrm{N} / \mathrm{L}$ 程度に設定した場合の脱窒反応は, $\mathrm{NO}_{3}-\mathrm{N}$ 濃度に関して零次反応に従うと判断した。

回分測定の際には, 空気中の酸素の溶解により脱窒反 応が阻害されないように容器を密閉し，ヘッドスペース を窒素ガスで置換する. 水温は連続処理装置と同じ值に 保つ. 経過時間ごとに約 $10 \mathrm{~mL}$ の污泥をサンプリング し, 直ちに $0.45 \mu \mathrm{m}$ のフィタでろ過し, ろ液の $\mathrm{NO}_{3}-\mathrm{N}$ 濃度を分析する. 回分反応開始から $2 \sim 3$ 時間ま での $\mathrm{NO}_{3}-\mathrm{N}$ 濃度がほぼ直線的に減少する範囲での減少 速度を $K_{D N}$ 亡する. また別に, 硝化槽污泥（または返 送污泥を污泥濃度調整のため処理水で希釈したもの）を 用い，同様に $K_{D N}$ を測定する．ただし硝化槽污泥を用 いる場合は液中に溶存酸素（DO）が残存するため, 回 分反応開始後，概ね 0.5 - 時間でそれが消費され，

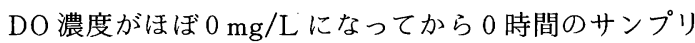
ングをする.

なお， $\mathrm{NO}_{3}-\mathrm{N}$ 濃度の分析にはイオンクロマトグラフ （横河電機製 IC 500）を用いた。このとき，同時に検 出される $\mathrm{NO}_{2}-\mathrm{N}$ 濃度は高々 $1 \mathrm{mg}-\mathrm{N} / \mathrm{L}$ と低く無視でき る程度であり, $\mathrm{NO}_{3}-\mathrm{N}$ 濃度のみを考慮することとした.

\section{（3）污泥内有機物量の算定方法}

森山ら ${ }^{5)}$ は, 硝化・内生脱窒法で運転された脱窒槽污 泥の脱窒反応が内生脱窒であるため, 脱窒槽液相中の有 機物濃度ではなく, 污泥内に蓄積・吸着された有機物量 がその制限因子になっているものとし，污泥内有機物量 を算定している. 硝化促進型循環変法や従来の活性污泥 循環変法では, 原水が直接脱窒槽に流入するが, 今回使 用した 3 系列の連続処理装置は，いずれも全反応槽容積 の 55 - 60\% を占める大型の脱窒槽を 1 槽のみ有し, そ れが十分に機械摫拌されている．そのため，原水中の溶 解性有機物は脱窒槽で希釈され，污泥に吸着されるなど して濃度が低下し，この場合も液相中の有機物濃度より むしろ污泥内有機物量が脱窒反応の制限因子になってい 
るものと予想された. そこで, 森山らの方法に従い, 污 泥内有機物量を $\mathrm{NO}_{3}-\mathrm{N}$ の脱窒に利用可能な有機物量 (BOD 量) として算定することとした.

脱窒回分反応を長時間継続すると, $\mathrm{NO}_{3}-\mathrm{N}$ 濃度 $C$ は 最終濃度 $C u$ に収れんし, 污泥内有機物量 $A$ は式（4） より間接的に求められる.

$$
A=m \cdot(C-C u) / X
$$

ここに, $A$ : 污泥内有機物量 $(\mathrm{mg}-\mathrm{BOD} / \mathrm{g}-\mathrm{SS})$

$m:$ 比例定数 $2.86(\mathrm{mg}-\mathrm{BOD} / \mathrm{mg}-\mathrm{N})$

$C: \mathrm{NO}_{3}-\mathrm{N}$ 濃度 $(\mathrm{mg}-\mathrm{N} / \mathrm{L})$

$\mathrm{Cu}$ : 最終 $\mathrm{NO}_{3}-\mathrm{N}$ 濃度 $(\mathrm{mg}-\mathrm{N} / \mathrm{L})$

$X:$ 污泥濃度 $(\mathrm{g}-\mathrm{SS} / \mathrm{L})$

また, $A$ の変化速度は $(5)$ 式で表される.

$$
\begin{aligned}
d A / d t & =(m / X) \cdot(d C / d t) \\
& =-m \cdot K_{D N}
\end{aligned}
$$

污泥内有機物の代謝速度が，污泥内有機物量に関する一 次反応式で近似できれば, 式 (6), 式 ( 7 ) が成り立つ.

$$
\begin{gathered}
A=A_{0} \cdot \exp (-k \cdot t) \\
d A / d t=-k \cdot A
\end{gathered}
$$

ここに, $k:$ 污泥内有機物の代謝速度定数 $(1 / \mathrm{h})$

$t:$ 時間 $(\mathrm{h})$

$A_{0}$ : 初期污泥内有機物量 $(\mathrm{mg}-\mathrm{BOD} / \mathrm{g}-\mathrm{SS})$ また, 式（5), 式（7）から式（8）が成り立つ.

$$
K_{D N}=(k / m) \cdot A
$$

式（8）加ら， $K_{D N}$ は污泥内有機物量 $A$ 亡污泥内有機 物の代謝速度定数 $k$ の積に比例する式で表わされる.

なお回分反応の継続時間内に最終 $\mathrm{NO}_{3}-\mathrm{N}$ 濃度 $C u$ が 得られない場合は, 森山らの方法と同様に, トーマス法 ${ }^{8)}$ を応用してそれを推定する。

\section{3. 実験結果及び考察}

\section{（1）連続処理系における脱窒速度}

\section{a）脱窒速度に及ぼす BOD-SS 負荷の影響}

連続処理装置の各系列について, 反応槽の BOD-SS 負荷 $\left(L_{\mathrm{BOD}}\right)$ と脱窒速度 $\left(K_{D N}\right)$ との関係を Fig.2 に示 す. 3 系列全体では, $L_{\mathrm{BOD}}$ が $0.83 \sim 14.5 \mathrm{mg}-\mathrm{BOD}_{5} / \mathrm{g}-$ $\mathrm{SS} / \mathrm{h}$, 水温が $12 \sim 27^{\circ} \mathrm{C}$ の間で変動したが, この範囲 では $L_{\text {BOD }}$ が高くなるほど $K_{D N}$ が約 $4 \mathrm{mg}-\mathrm{N} / \mathrm{g}-$ $\mathrm{SS} / \mathrm{h}$ まで比例的に大きくなる傾向があり, 全水温につ いて式（9）により近似された.

$$
K_{D N}=0.283 L_{\mathrm{BOD}}
$$

ここに, $K_{D N}$ : 脱窒速度 $(\mathrm{mg}-\mathrm{N} / \mathrm{g}-\mathrm{SS} / \mathrm{h})$

$$
L_{\text {BOD }} \text { : BOD-SS 負荷 }\left(\mathrm{mg}-\mathrm{BOD}_{5} / \mathrm{g}-\mathrm{SS} / \mathrm{h}\right)
$$

この結果から， $L_{\mathrm{BOD}}$ が $K_{D N}$ に対する重要な影響因子で あり， $L_{\mathrm{BOD}}$ がより高く運転される硝化促進型循環変法

(実証装置及び PP 1) が, 従来の循環変法 (PP 2)

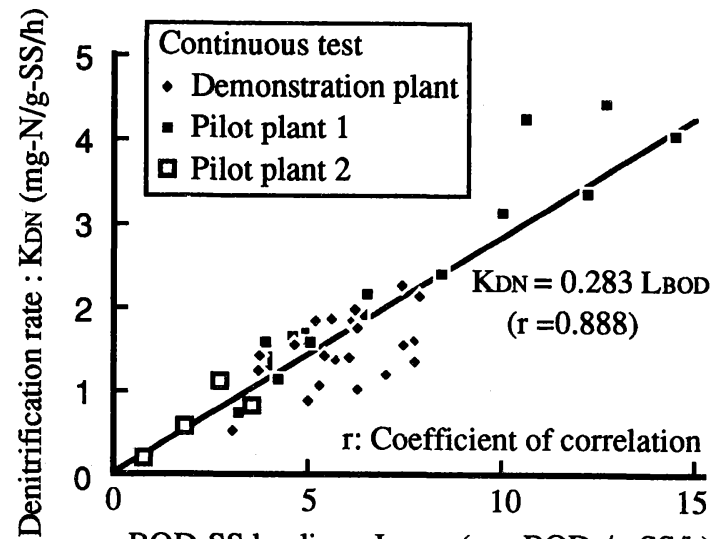

BOD-SS loading : LBOD (mg-BODs/g-SS/h)

Fig.2 Relation between BOD-SS loading and denitrification rate

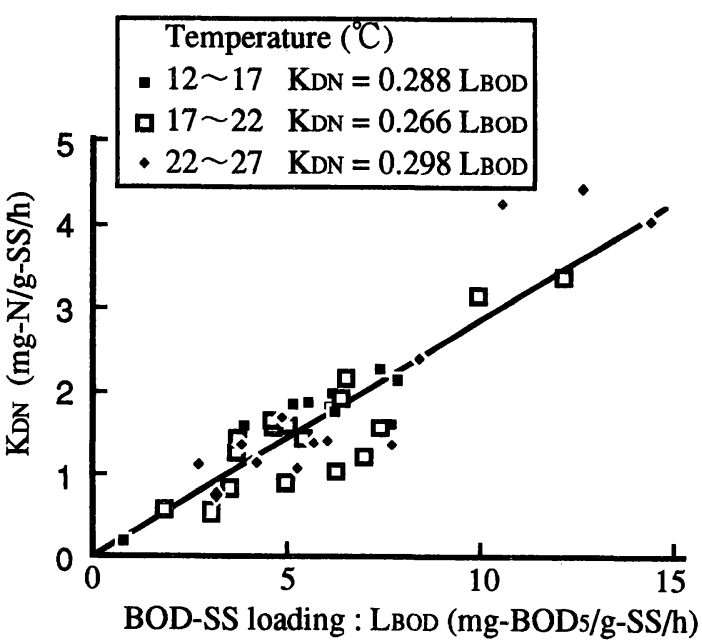

Fig.3 Denitrification rate at different temparatures

に比べて $K_{D N}$ が大きくなることを確認できた。

b）脱窒速度に及ぼす水温の影響

Fig.2 に示した $L_{\mathrm{BOD}}$ と $K_{D N}$ との関係について, さら に水温ごとに分類した結果を Fig.3に示す. 水温を 12 $\sim 27{ }^{\circ} \mathrm{C}$ の範囲で低水温〜高水温の 3 段階に分類し, そ れぞれの比例係数を求めた結果, いずれの温度範囲でも

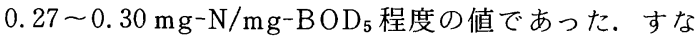
わち, $K_{D N}$ は $12 \sim 27^{\circ} \mathrm{C}$ の範囲であまり水温の影響を受 けない結果が得られた。

\section{（2）回分測定による脱窒速度}

\section{a) 脱窒槽污泥の脱窒速度}

連続処理装置の脱窒槽污泥を採取し, 系外で新たに $\mathrm{NO}_{3}-\mathrm{N}$ を添加して污泥のもつ脱窒能力を回分測定によ る $K_{D N}$ として求め, これと連続処理系おける実際の 


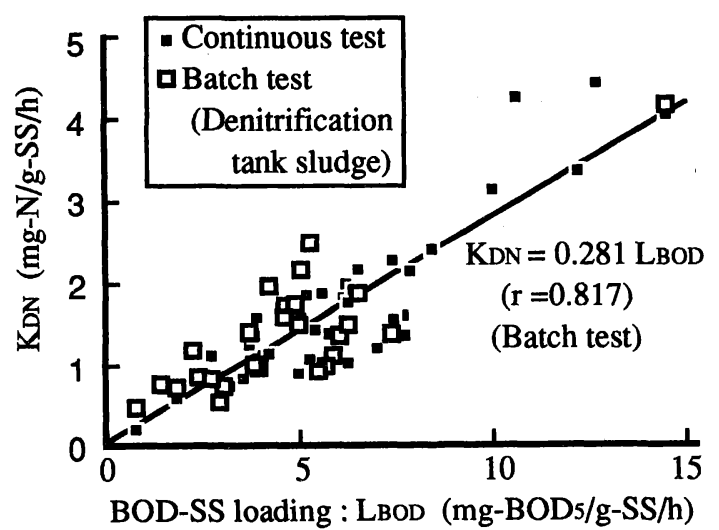

Fig.4 Denitrification rate of denitrification tank sludge

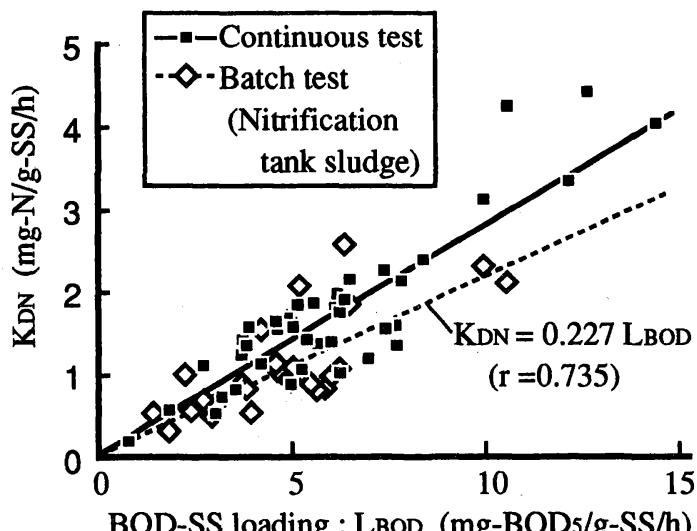

Fig.5 Denitrification rate of nitrification tank sludge

$K_{D N}$ とを比較した。連続処理装置の $L_{\mathrm{BOD}}$ と回分測定に よる $K_{D N}$ ，及び連続処理系における $K_{D N}$ との関係を Fig.4 に示す. 両 $K_{D N}$ は同等の値を示していることから， 連続系での実際の $K_{D N}$ も $\mathrm{NO}_{3}-\mathrm{N}$ 濃度による律速はほと んビなく, 脱窒反応は, $K_{D N}$ の算出の対象とした脱窒槽 の $\mathrm{NO}_{3}-\mathrm{N}$ 濃度が $0.2 \mathrm{mg}-\mathrm{N} / \mathrm{L}$ 以上の場合にほぼ零次反 応に従うこと，及び $L_{\mathrm{BOD}}$ が $K_{D N}$ の重要な影響因子であ ることが裏付けられた。

\section{b）硝化槽污泥の脱窒速度}

脱窒槽での脱窒反応は, 硝化槽污泥 (または返送污泥) が脱窒槽に循環され流入原水之混合して生じる。 そのた め, 硝化槽污泥がもつ $K_{D N}$ を把握することも脱窒反応 の解析に重要である．そこで硝化槽污泥（または返送污 泥を処理水で希釈した液）を用いて $K_{D N}$ を回分測定し た. $L_{\mathrm{BOD}}$ と $K_{D N}$ との関係を Fig.5に示す．また，Fig.4 之同じく連続処理系における脱窒槽の $K_{D N}$ を合わせて 示す．硝化槽污泥も，嫌気条件を整えることにより脱窒 性能を示した。 この $K_{D N}$ は, ややばらつきの大きいプ ロットもみられるが $L_{\mathrm{BOD}}$ とほぼ比例関係にあり（相関
Table 3 Calculation for the amount of accumulated organic matter in sludge (Examples of denitrification tank sludge of PP 1, PP 2 )

\begin{tabular}{|l|c|c|}
\hline & P P 1 & P P 2 \\
\hline BOD-SS loading: LBOD (mg-BODs/g-SS/h) & 4.96 & 2.30 \\
\hline M L S S: $\quad \mathrm{X} \mathrm{(g/L)}$ & 1.39 & 1.66 \\
\hline Initial N O3-N: Co (mg/L) & 36.7 & 40.7 \\
\hline Final N O3-N : C u (mg/L) & 0.4 & 17.0 \\
\hline $\begin{array}{l}\text { Metabolism rate constant } \\
\text { of accumulated organic matter : k (1/h) }\end{array}$ & 0.0714 & 0.0716 \\
\hline $\begin{array}{l}\text { Initial amount of accumulated organic } \\
\text { matter in sludge : Ao (mg-BOD/g-SS) }\end{array}$ & 74.6 & 40.0 \\
\hline $\begin{array}{l}\text { Denitrification rate calculated } \\
\text { by equation (8): KDN' (mg-N/g-SS/h) }\end{array}$ & 1.86 & 1.00 \\
\hline $\begin{array}{l}\text { Denitrification rate obtained from } \\
\text { batch test (0 3h) : KDN (mg-N/g-SS/h) }\end{array}$ & 1.73 & 0.99 \\
\hline
\end{tabular}

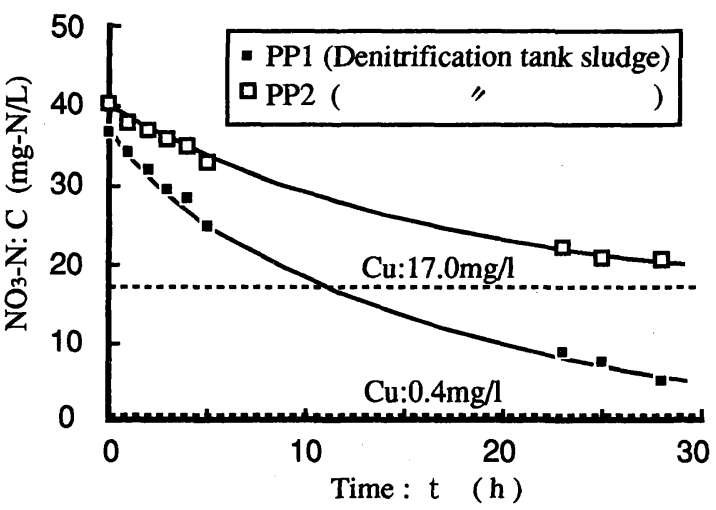

Fig.6 Change of $\mathrm{NO}_{3}-\mathrm{N}$ (Batch test)

係数 $r=0.735$ ), 脱窒槽の $K_{D N}$ (連続処理系) の概ね 70 〜 $80 \%$ の值を示した。この結果から, 硝化槽污泥も, 後に述べる污泥内有機物量を多く有しており，これが脱 窒槽に循環されて脱窒槽の $K_{D N}$ に大きく影響している と考えられる. そこで以後の検討には, 脱窒槽污泥に加 えて硝化槽污泥に関するデータも用いることとした。

なお, 硝化槽污泥の $K_{D N}$ が脱窒槽の $K_{D N}$ と比較して 幾分低下するのは，硝化槽では污泥内有機物が酸化反応 により代謝され，その量が脱窒槽における污泥内有機物 量より減少しているためと考えられるが，この点につい ては今後さらに検討をすすめる予定である.

\section{（3）污泥内有機物量の算定例}

一例として, 水温が $23^{\circ} \mathrm{C}$ で運転された PP $1, \mathrm{PP} 2$ のそれぞれの脱窒棤污泥を採取し, 前述の実験方法 (3) 項に基づき污泥内有機物量を求めた. このときの PP 1 と PP 2 の $L_{\mathrm{BOD}}$, 脱窒回分反応における初期の污泥濃度 $X$, 初期 $\mathrm{NO}_{3}-\mathrm{N}$ 濃度 $C_{0}$ をそれぞれ Table 3 に示す．ま た， $\mathrm{NO}_{3}-\mathrm{N}$ 濃度 $C$ の経時変化を Fig.6 に示す. いずれ の污泥を用いた場合も, 時間の経過とともにC の減少 の度合いが小さくなる曲線が得られた．28時間までの 


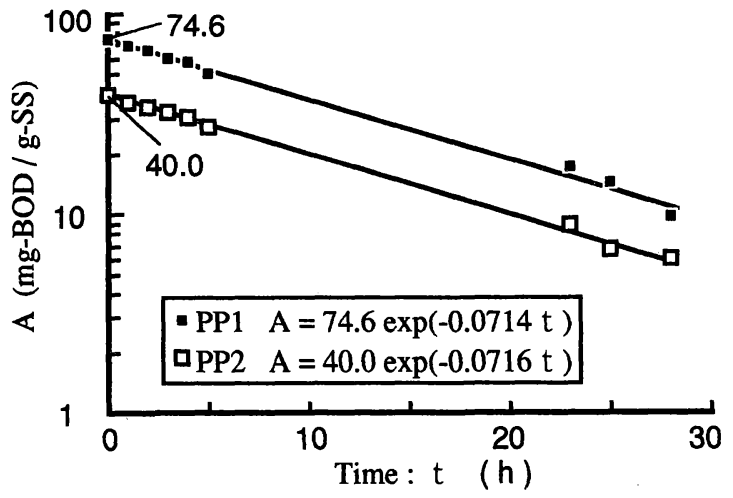

Fig.7 Change of the amount of the accumulated organic matter in sludge : $A$

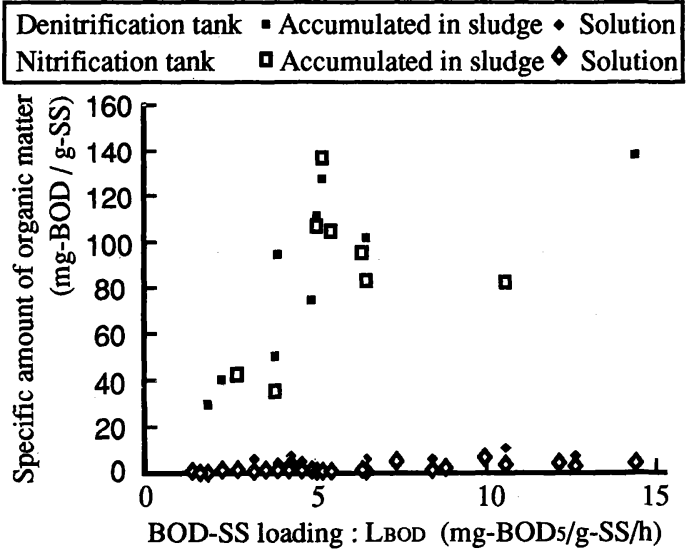

Fig.8 Relation between BOD-SS loading and Specific amount of organic matter

であり， $A$ の概ね $1 / 20$ と少なかった。ここで BOD 量 の換算値は, $\mathrm{BOD}_{5}$ 濃度の分析値に, $\mathrm{BOD}_{5}$ 濃度に対す る最終 BOD 濃度の比 $U$ を乗じ, さらに污泥濃度 $X$ で 割って求めたものである.なお, 最終 BOD 濃度は, 試 料に硝化抑制型の微生物製剤を植種し，BOD テスター による 10 日までの酸素消費量からトーマス法を利用し て算定した. $U$ の平均值として 1.3 が得られており, この値を換算に用いた。

\section{（4）污泥内有機物量と脱窒速度との関係}

連続処理装置の $L_{\mathrm{BOD}}$ と, 脱窒槽污泥及び硝化槽污泥 について算定した污泥内有機物量 $A$ (前項（3）での初 期污泥内有機物量 $A_{0}$ に相当）との関係を Fig. 8 に示す. また，污泥のNo. 5 A 万紙によるろ液中の BOD 量を同 時に示す.いずれの $L_{\mathrm{BOD}}$ でも，ろ液中の $\mathrm{BOD}$ 量は数 $\mathrm{mg}-\mathrm{BOD} / \mathrm{g}-\mathrm{SS}$ 程度以下であり，A と比較して極めて 少ない結果が得られた.このことから，各槽内の有機物 量のうち液相中の有機物量は無視でき，ほぼ全量が污泥 内に蓄積されたものとみなせた。 また, 内生脱窒を行っ ている污泥内の有機物量を算定する森山らの方法を, こ こで利用したことの妥当性を確認できた。なお，具体的 な污泥内有機物の形態としては, 森山らが指摘している ように，原水中の有機物やそれが活性污泥フロックに吸 着されたもの, 溶解性有機物が菌体構成成分や貯蔵物質 に転換したものなよ゙が考えられる5.

次に, Fig.9に $A$ と $K_{D N}$ との関係を示す. Fig.8, Fig.9のいずれにおいても各変数の間に大まかには比例 関係が認められるが，プロットにばらつきがみられる.

そこで, $L_{\mathrm{BOD}}$ と $A, A$ と $K_{D N}$ のそれぞれの関係に及 ぼす水温の影響を調べるため, 各変数の比,すなわち $\left(A / L_{\mathrm{BOD}}\right),\left(K_{D N} / A\right)$ と水温との関係をそれぞれ Fig.10, Fig.11 に示す.なお, $\left(A / L_{\mathrm{BOD}}\right)$ は, 污泥内有機物量が 


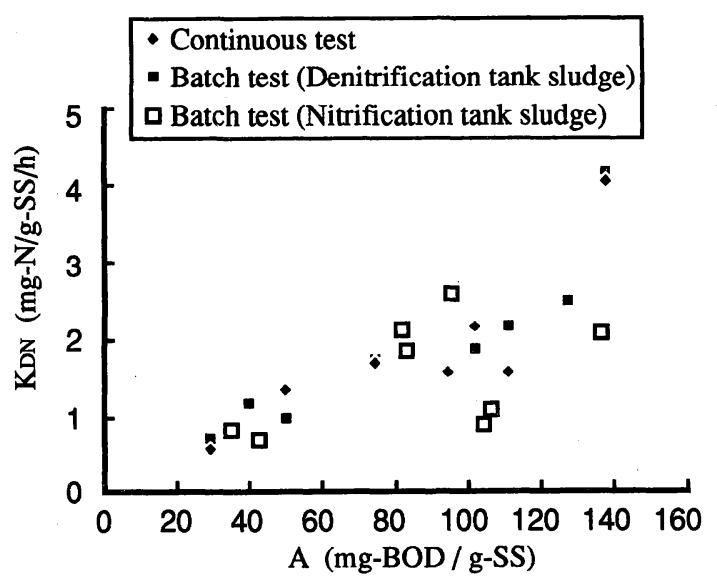

Fig.9 Relation between amount of accumulated organic matter in sludge $(A)$ and denitrification rate $\left(K_{D N}\right)$

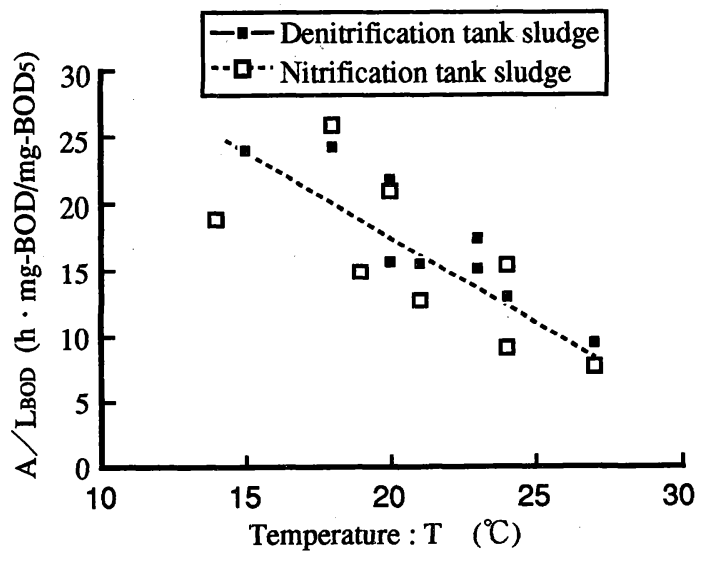

Fig.10 Relation between temperature and $A / L_{\mathrm{BOD}}$

原水中の $\mathrm{BOD}$ によって入れ変わる時間，すなわち有機 物の污泥内貯留時間を意味する.また, $\left(K_{D N} / A\right)$ は式 $(8)$ 加, 污泥内有機物の代謝速度定数 $k$ を比例定数 $m$ (2.86) で割った値 $(k / 2.86)$ に置き換えられる. Fig.10 で, $\left(A / L_{\mathrm{BOD}}\right)$ は水温が低いほど大きく,また Fig.11 で, $(k / 2.86)$ すなわち $k$ は水温が高いほど大きくなる傾向 が認められた.これらのことから, 水温が変動する場合, 例えば水温が低下すると $k$ が小さくなり, 脱窒反応に 伴う污泥内有機物の代謝があまり進まなくなるが，その 結果として污泥内に有機物が長時間貯留され $A$ が増加 する. $K_{D N}$ は $k$ 之 $A$ の積に比例するため, Fig.3 で $K_{D N}$ はあまり水温の影響を受けない結果となったと考えられ る.

なお，硝化槽污泥は脱窒槽污泥と比較して，Fig.10 では同一の $L_{\mathrm{BOD}}$ のとき $A$ がやや少なくなり, Fig.11で は $k$ がやや小さくなる傾向がみられる.このことから 硝化槽污泥は脱窒槽污泥よりも, 酸化反応に伴う代謝に

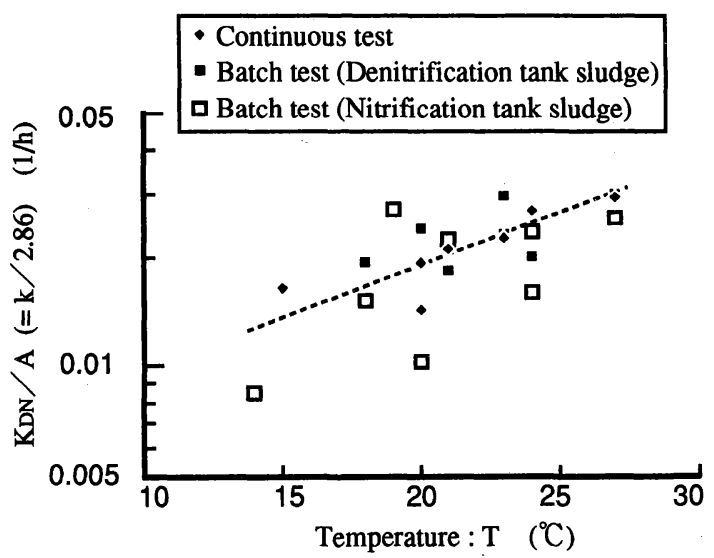

Fig.11 Relation between temperature and $K_{D N} / A(=k / 2.86)$

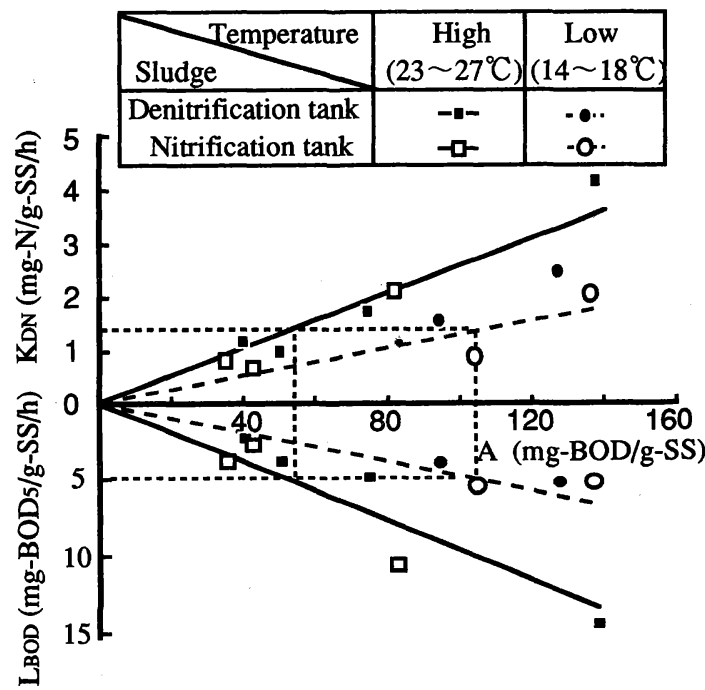

Fig.12 Relation among $L_{\mathrm{BOD}}, A$ and $K_{D N}$

より污泥内有機物量が減少している上，その代謝のされ 易さもやや低下しているものと考えられる．また，これ が Fig.5 で硝化槽污泥の $K_{D N}$ が脱窒槽の $K_{D N}$ より小さ くなった原因と推定される.

以上の水温の因子を含む $L_{\mathrm{BOD}}, A, K_{D N}$ の関係を Fig.12にまとめて示す.これは, Fig.10 と Fig.11 から 低水温 $\left(14 \sim 18^{\circ} \mathrm{C}\right)$ と高水温 $\left(23 \sim 27^{\circ} \mathrm{C}\right)$ のプロット を選んだものである。例えば $L_{\mathrm{BOD}}$ が $5 \mathrm{mg}-\mathrm{BOD}_{5} / \mathrm{g}-$ $\mathrm{SS} / \mathrm{h}$ のとき, 低水温では $A$ は $105 \mathrm{mg}-\mathrm{BOD} / \mathrm{g}-\mathrm{SS}$ 程 度で比較的多いが $\left(K_{D N} / A\right)$ は小さい, 逆に, 高水温で は $A$ は $55 \mathrm{mg}-\mathrm{BOD} / \mathrm{g}-\mathrm{SS}$ 程度で比較的少ないが $\left(K_{D N} / A\right)$ は大きい. 結果として, いずれの水温でも, $K_{D N}$ は式 (9) から求められる $1.42 \mathrm{mg}-\mathrm{N} / \mathrm{g}-\mathrm{SS} / \mathrm{h}$ で 同程度になることが示される.また， $L_{\mathrm{BOD}}$ が変動する 場合, $A$ が $L_{\mathrm{BOD}}$ にほぼ比例するため, 結果として $K_{D N}$ 
は $L_{\mathrm{BOD}}$ にほぼ比例することが明らかとなった。

\section{4. 結言}

硝化促進型循環変法及び従来の活性污泥循環変法で運 転した 3 系列の連続処理装置（実証装置と 2 系列のパイ ロットプラント）を使用し，浮遊污泥の脱窒速度に及ぼ す BOD SS 負荷及び水温の影響を検討した．また，脱 窒槽及び硝化槽の污泥内に蓄積された有機物に着目し, その量と脱窒速度との関係を検討した結果，以下の知見 を得た。

（1）反応槽の BOD-SS 負荷 $\left(L_{\mathrm{BOD}}\right)$ が $0.83 \sim 14.5$ $\mathrm{mg}-\mathrm{BOD}_{5} / \mathrm{g}-\mathrm{SS} / \mathrm{h}$ の範囲で, 単位污泥量あたりの脱窒 速度 $\left(K_{D N}: \mathrm{mg}-\mathrm{N} / \mathrm{g}-\mathrm{SS} / \mathrm{h}\right)$ はほぼ $L_{\mathrm{BOD}}$ に比例した。 比例係数として $0.283 \mathrm{mg}-\mathrm{N} / \mathrm{mg}-\mathrm{BOD}_{5}$ を得た。

（2） $K_{D N}$ は, 水温が $12 \sim 27^{\circ} \mathrm{C}$ の範囲では, その影 響をあまり受けない。

（3）回分反応における脱窒可能 $\mathrm{NO}_{3}-\mathrm{N}$ 濃度から間 接的に算定した各槽の污泥内有機物量 $(A$ : $\mathrm{mg}-\mathrm{BOD} / \mathrm{g}-\mathrm{SS})$ に対し, 污泥のろ液中の BOD 量 $(\mathrm{mg}-\mathrm{BOD} / \mathrm{g}-\mathrm{SS})$ は $1 / 20$ 程度と少なく, 槽内の有機 物は，ほぼ全量が污泥内に蓄積されたものとみなせた。

（4） $K_{D N}$ は $A$ 亡污泥内有機物の代謝速度定数（ $k$ : $1 / \mathrm{h})$ の積に比例する式 $K_{D N}=(k / m) \cdot A(m$ は定数 $)$ で表された。水温が低下した場合， $k$ が小さく，脱窒反 応に伴う污泥内有機物の代謝が進まなくなり，その結果
として $A$ が増加するため, $K_{D N}$ はあまり水温の影響を 受けない. また， $L_{\mathrm{BOD}}$ が変動した場合， $A$ が $L_{\mathrm{BOD}}$ にほ ぼ比例するため, 結果として $K_{D N}$ は $L_{\mathrm{BOD}}$ にほぼ比例し た.

\section{参考文献}

1）包括固定化担体を用いた硝化促進型循環変法「ペガサス」 の評価に関する報告書，日本下水道事業団技術開発部， 1993.

2）竹島正，茂木勝三，中村裕紀，江森弘祥：硝化促進型循 環変法における脱窒速度の検討, 第 30 回下水道研究発表 会講演集, pp. 530-532, 1993.

3）日野達夫, 田中和博, 江森弘祥, 中村裕紀：硝化促進型 循環変法における脱窒速度について, 第 31 回下水道研究 発表会講演集, pp. 482-484, 1994.

4）橋本奖, 古川憲治：微生物脱窒反応の基質依存性に関す る研究, 下水道協会誌, Vol. 15, No. 175, pp. 20-29, 1978.

5）森山克美，高橋正宏，原田良誠，北村武之：硝化・内生 脱窒法における脱窒反応速度に関する研究：下水道協会 誌論文集, Vol. 29, No. 339, pp.65-73, 1993.

6）茂木勝三, 青木正信, 江森弘祥, 中村裕紀：硝化促進型 循環変法の実規模施設への適用, 第 29 回下水道研究発表 会講演集, pp. 530-532, 1992.

7) Process Design Manual for Nitrogen Removal, U.S.EPA, Office of Tachnol. Transf. Washington D.C., 1974.

8) Thomas, A. H. Jr. : Graphical Determination of BOD Curve Constants, Water and Sewage Works, Vol.97, pp.123-124, 1950.

(1994. 8. 29 受付)

\title{
INFLUENCE OF BOD LOADING AND TEMPERATURE ON DENITRIFICATION RATE OF THE HIGH RATE NITROGEN REMOVAL PROCESS USING IMMOBILIZED NITRIFIERS
}

\author{
Hiroki NAKAMURA, Hiroyoshi EMORI, Tadashi TAKESHIMA \\ and Kazuhiro TANAKA
}

\begin{abstract}
Denitrification rate $\left(K_{D N}\right)$ of suspended activated sludge in the high rate nitrogen removal process using immobilized nitrifiers was investigated in relation to BOD-SS loading and temperature. A demonstration plant and two pilot plants were operated with BOD-SS loading from 0.83 to $14.5 \mathrm{mg}-\mathrm{BOD}_{5} / \mathrm{g}-\mathrm{SS} / \mathrm{h}$ and temperature from 12 to $27^{\circ} \mathrm{C}$. $K_{D N}(\mathrm{mg}-\mathrm{N} / \mathrm{g}-\mathrm{SS} / \mathrm{h})$ was almost proportional to the amount of accumulated organic matter $(A)$ multiplied by its metabolism rate constant $(k)$. $K_{D N}$ changed little with the seasonal change of temperature, as the $A$ value increased with the decreasing temperature, though decreased the $k$ value. It was found the proportional increase of the $A$ value to BOD-SS loading resulted in the proportional increase of $K_{D N}$.
\end{abstract}

